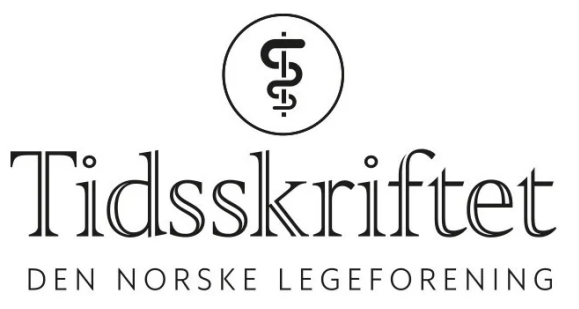

\title{
Kan parasittinfeksjon øke risikoen for hiv?
}

NYHETER

\section{HANNE STØRE VALEUR}

Email: hanne.store.valeur@legeforeningen.no

Tidsskriftet

Nyere forskning viser at parasitten Schistosoma haematobium kan føre til forandringer i genitale slimhinner som er forenlig med økt risiko for hivinfeksjon. 


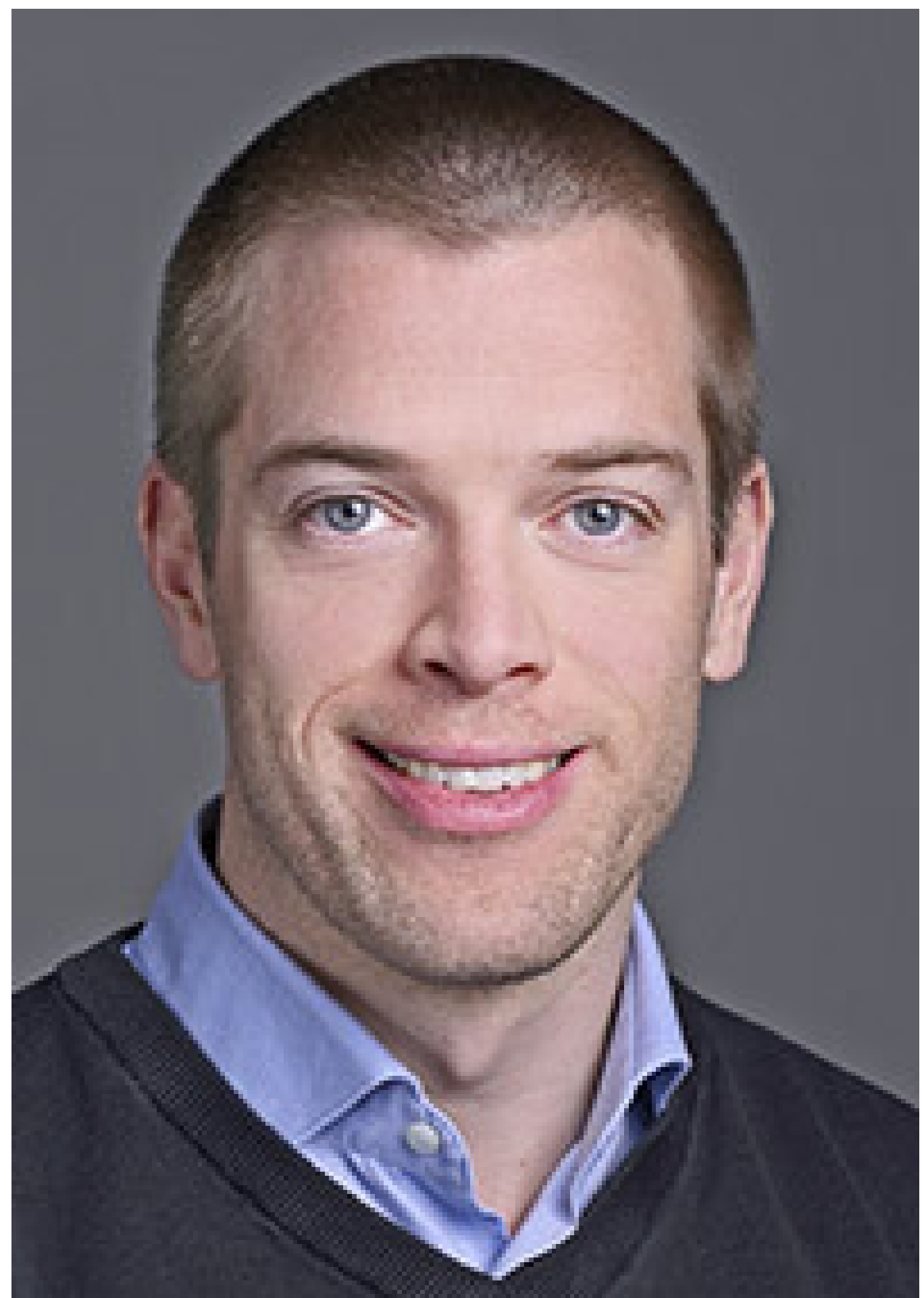

Peter Mark Jourdan. Foto Håvard Storvestre, BA fotografene

Parasittsykdommen schistosomiasis er nesten like vanlig som malaria og rammer millioner som lever under dårlige sanitære forhold uten rent vann. De fleste vet ikke at de er smittet og får ikke tilgang til enkel, forebyggende behandling. Mange smittede bor i områder som også er hardt rammet av hivepidemien, og studier har antydet en sammenheng mellom kvinnelig genital schistosomiasis og hiv. Mulige mekanismer for dette har hittil ikke vært kjent.

Jourdan har i doktorgradsavhandlingen Schistosoma haematobium infection in the female genital mucosa undersøkt immunfarget snitt av biopsier fra genital slimhinne fra kvinner med schistosomiasis og funnet økt antall målceller for hiv, CD4+ T-lymfocytter og makrofager rundt parasitteggene. Parasittinfisert vev har også større tetthet av blodkar enn 
i vev fra friske kvinner, noe som sannsynligvis gir slimhinneblødning og redusert barriere mot hiv. Videre har Jourdan og medarbeidere utviklet en enkel metode for å analysere vevsprøver med tanke på parasitter og andre forsømte sykdommer i utviklingsland.

Behandling av schistosomiasis består av en enkelt tablettdose som er rimelig og godt tolerert. Verdens helseorganisasjon anbefaler årlig behandling av alle innbyggere i høyendemiske områder, men grunnet økonomiske og logistiske begrensninger er det få som behandles. I videre forskning vil man se nærmere på om behandling av schistosomiasis kan redusere kvinnelig genital schistosomiasis og om dette derved kan bidra til å bremse hivepidemien.

\section{Disputas}

Peter Mark Jourdan disputerte for ph.d.-graden ved Universitetet i Oslo 7.2. 2013. Tittelen på avhandlingen er Schistosoma haematobium infection in the female genital mucosa. Immunohistochemical and clinicopathological analyses with respect to HIV target cells and vascularity in cervicovaginal tissue. Cross-sectional studies in Malawi and Madagascar.

Publisert: 9. april 2013. Tidsskr Nor Legeforen. DOI: 10.4045/tidsskr.13.0234

(C) Tidsskrift for Den norske legeforening 2023. Lastet ned fra tidsskriftet.no 26. april 2023. 